\title{
Histopathological Effects of Aloe barbadensis and Soybean Oil on Rat Liver
}

\author{
Efectos Histopatológicos de Aloe barbadensis y Aceite de Soya en Hígado de Rata
}

\author{
"Rengin Kosif; **Fahri Yılmaz; **** Gülsün Akdemir Evrendilek \& *Murat Dıramalı
}

KOSIF, R.; YıLMAZ, F.; EVRENDILEK, G. A. \& DiRAMALı, M. Histopathological effects of Aloe barbadensis and soybean oil on rat liver. Int. J. Morphol., 28(4):1101-1106, 2010.

SUMMARY: Aloe Barbadensis, which is a species of Aloe vera, is a popular plant used by the common people and in alternative medicine. This study aimed to analyze the effects of Aloe Barbadensis and soybean oil on liver. For this study Wistar Albino female rats were taken and divided into 3 equal groups; the first group was the control group wherein no treatment was applied, second group in which the dissolved form of $A$. barbadensis in the soybean oil was applied ( $25 \mathrm{mg} /$ day), and the third group which only soybean oil was applied (500 mg/day). Biopsy materials were taken from the lobus dexter of the livers of the rats and analyzed with light microscope after the necessary standard processing of histologic slides. Group I demonstrated normal structural characteristics of rat liver. In Group II and Group III, we observed nuclear enlargement, mild increase in chromatin and hydropic degeneration and binucleation in some hepatocytes. Liver histology demonstrated congestion in portal veins, sinusoids and the central veins. Merely in Group III, portal venous congestion and in Group II sinusoidal congestion was evident parenchyma of the liver. Additionally in Group III liver histology demonstrated plasmocyte infiltration in portal areas. Our study showed that using soybean with Aloe Barbadensis is synergystic and increasing each others effects. However we didn't observe mononeuclear infiltrations in Group II, these show antinflammatory effects of Aloe Barbadensis. It is determined that, depending on the used dose of Aloe Barbadensis, the toxic effect can change. If Aloe Barbadensis used very high doses it can have toxic effect on hepatocytes.

KEY WORDS: Aloe barbadensis; Soybean; Rat; Liver; Effect.

\section{INTRODUCTION}

Aloe vera is a very popular plant which was used for alternative medicine (Paulsen et al., 2005). Aloe vera also known as medicinal aloe has been used to treat different diseases due to its therapeutic effects. It is one of the most known medicinal plants since ancient times and was used as traditional medicine in Egypt, China and in different European Countries. A. vera is a stemless or very shortstemmed succulent plant growing to $60-100 \mathrm{~cm}$ tall, spreading by offsets. The plant is divided into three sections which are the skin, latex and gel layers. Approximately after four-year-growing-period, the plant is maturated, and the gel layer inside and sap outside get mixed by forming the mixture which has the therapeutic effect. In parallel to other countries, the use of $A$. vera as a medicinal plant has been increasing in Turkey recently (Tekin et al., 2007).
It was reported that $A$. vera gel contains more than 70 biologically active compounds carrying antiinflammatory, antioxidant, anti-carcinogenic, anti-aging, anti-diabetics properties, and they also effective in improving the immune system and curing the diseases that result from a deficient immune system (Grindlay \& Reynolds, 1986). It was also reported that high molecular weight compounds are responsible for the therapeutic effects of A. vera (Egger et al., 1996; Shida et al., 1985). Isolated polysaccharides from the jel matrix have immunopotential effects, increase the phagocytosis, and lectin-like proteins which play a role in the antiinflammatory effects (Grindlay \& Reynolds; Shida et al.). It has been reported that $A$. vera extracts contain several components like prostaglandins and bradykinin-degrading

\footnotetext{
* Abant Izzet Baysal University Faculty of Medicine Department of Anatomy Golkoy Campus 14280 Bolu Turkey.

** Abant Izzet Baysal University Faculty of Medicine Department of Pathology Golkoy Campus 14280 Bolu Turkey.

**** Abant Izzet Baysal University Faculty of Engineering and Architecture Department of Food Engineering Golkoy Campus 14280 Bolu Turkey.
} 
glycoprotein can explain the anti-inflammatory effects of A. vera extract (Azfal et al., 1991; Yagi et al., 1987).

Conducted in vitro studies showed the antiproliferative effect of $A$. vera on human liver cancer cell (Kuo et al., 2002). In addition to therapeutic effect of A. vera gel in vitro, it was revealed that it has cytotoxic effect on not only tumor cells but only normal cells (Winters et al., 1981; Danhof et al., 1983). According to Avila et al., (1997) it was thought that green shoot of A. vera is very rich with anthraquinon that could have an adverse effect on cell growth. Low molecular weight compounds such as aloin is held responsible for this cytotoxicity (Avila et al.). Regarding the liver toxicity of $A$. vera only two cases were reported in the literature (Tekin et al.; Rabe et al., 2005).

Aloe barbadensis, one of the A. vera species is one of the most common used medicinal plant for therapeutic uses in North America, Europe, and Asia. Plants containing A. barbadensis have also been used as an anti-inflammatory agent, for the therapy of ulcer, hepatitis and neoplasias, and also for wound healing (Kim et al., 1999). It has been reported that it stimulates macrophages and also has antiviral effects (Zhang et al., 1996). Antioxidative, antigenotoxic and chemo-preventive effects of $A$. barbadensis have been showed in several studies (Hu et al., 2003; Lee et al., 2000; Kim \& Lee, 1997).

Soybean has been used in Asia, Middle East and Africa to promote health and protected from diseases (Kanamoto et al., 2001; Gali-Muhtasib et al., 2004). Antioxidant effects of soybean were reported in many pathological conditions (Wei et al., 1995; Rodrigues et al., 2005). El Gendy et al. (2007) suggested that oral feeding of the diet containing soybean antagonized the oxidative stress effects induced during experimental hepatocarcinogenesis by nitrosamine precursors (El Gendy et al.).

Several studies reported the effect of soybean oil on liver. A study conducted by Nishimura et al. (2006) reported that soybean oil prevent liver damage related to parenteral nutrition. In another study it was emphasized that soybean oil regulates the blood and liver lipid level in a positive way (Lin et al., 2005). According to Kamei et al. study (1995), accumulation of cholesterol in the body was reduced and cholesterol excretion was enhanced effectively in rats given the highly hydrogenated soybean oil-rich diet (Kamei et al., 2005).

Although the effects of A. barbadensis and soybean oil have been reported in different studies, literature lacks information on the effect of both on liver. Therefore, the objective of the study was to determine the effect of $A$. barbadensis dissolved in soybean oil and soybean oil alone on liver of Wistar Albino female rats.

\section{MATERIAL AND METHOD}

Animals: The 18 Wistar Albino female rats of three months olds from Zonguldak Karaelmas University Faculty of Medicine Experimental Research Center (Zonguldak, Turkey) were obtained after receiving the permission from the ethics commission to study with animals. The weights of the rats were between 170-200 gr (mean 177.51 $18.7 \mathrm{gr}$ ).

Preparation of A. barbadensis and soybean oil: Aloe barbadensis used in the study was in the form of softgel capsule. Each capsule contains $25 \mathrm{mg}$ Aloe barbadensis leaf extract and $500 \mathrm{mg}$ soybean oil as a solvent (Leiner Health Products, Ca, USA). Organic natural soybean oil was used for $500 \mathrm{mg} /$ day dose (Ihlamur Naturel Food products-Aggroland, Ankara, Turkey).

Treatments of the animals: Rats were kept under the same biological and physiological conditions. The temperature of the laboratory was $23 \pm 2^{\circ} \mathrm{C}$, the relative humidity was $\%$ 40 and the laboratory had 12-h lightness/darkness cycles. The animals kept under these conditions were equally divided into 3 groups; control (group 1), Aloe barbadensis dissolved in soybean oil administered group (group 2) and only soybean oil administered group (group 3), respectively. A. barbadensis was administered to second group in a daily dose of $25 \mathrm{mg}(140 \mathrm{mg} / \mathrm{kg}$ ) for 3 weeks. The third group was administered only soybean oil of $500 \mathrm{mg} /$ day dose for 3 weeks. A. barbadensis and soybean oil were administered rats in group 2 and 3 between 10:00 and 11:00 a.m. per each day orally and by applying gavages. All of the three groups were fed with normal feed and water ad libitum.

Preparation of samples for microscopic analyses: After 3 weeks of feeding, on the 21st day; animals were deeply anesthetized with thiopental sodium and then perfused with $10 \%$ formaldehyde. Abdomen was opened and all biopsy materials were taken from the right lobe of the liver of the female rats. For microscopic examination, the biopsy materials were dehydrated in alcohol series, processed in xylene and then embedded in paraffin. Sections taken at 0.4-0.6 micron thicknesses from each specimen were stained with Hematoxylene \& Eosin. All sections were comparatively evaluated under Olympus BX51 light microscope at X40, X100, X200 and X400 magnification and then pictures were taken for examination. 


\section{RESULT AND DISCUSSION}

Results from the control group showed that the incisions from the liver tissue of central veins, portal areas and sinusoids appeared normal (Fig.1).

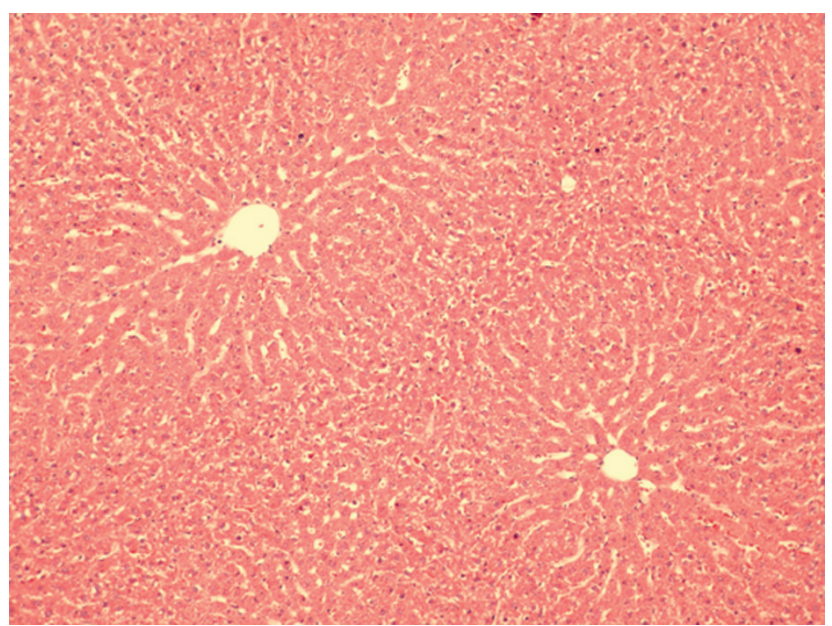

Fig. 1. Portal areas and sinusoids of control group rat liver(H\&E, X100).

Histopathological examination of group 2 samples feed with $25 \mathrm{mg}$ of Aloe barbadensis dissolved in $500 \mathrm{mg}$ soybean oil revealed slight enlargement and congestion of central vein of whole liver, nuclear enlargement of hepatocytes, mild increase in chromatin, hydrophic degeneration and binucleation in some hepatocytes. It was very interesting to observe enlargement of sinusoids and erythrocyte accumulation in portal veins. However, congestion in central veins was much more distinct than that of portal veins (Figs. 2, 3 and 4).

In group 3, which was feed with $500 \mathrm{mg}$ soybean oil only, histopathological observations revealed distinct enlargement of central veins and erythrocyte accumulation, enlargement of sinusoids and congestion. Slight nuclear chromatin increase in hepatocytes and binucleation was very distinct. Congestion in portal veins and enlargement along with mononuclear cell (plasmocyte) infiltration was observed. Congestion in these portal veins was more distinctive than that of central vein (Figs. 5, 6, 7 and 8).

There are limited studies reported toxic effects of $A$. vera in the literature. In previously conducted two studies reporting the toxic effect of $A$. vera on liver (Tekin et al.; Rabe et al.). A male patient after the use of $A$. vera for 20 days (the applied dose was not revealed) came to hospital with whole body of a deep yellow and darkness in his urine was diagnosed with toxic hepatitis (Tekin et al.). Another patient also used $A$.

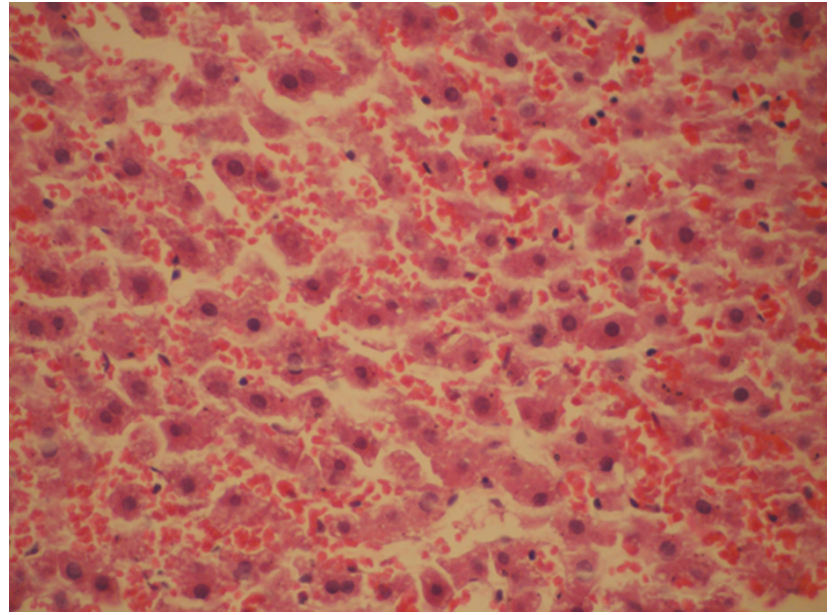

Fig. 2. Binucleation in hepatocytes, nuclear enlargement, hydropic degeneration and chromatin increase (H\&E, X400).

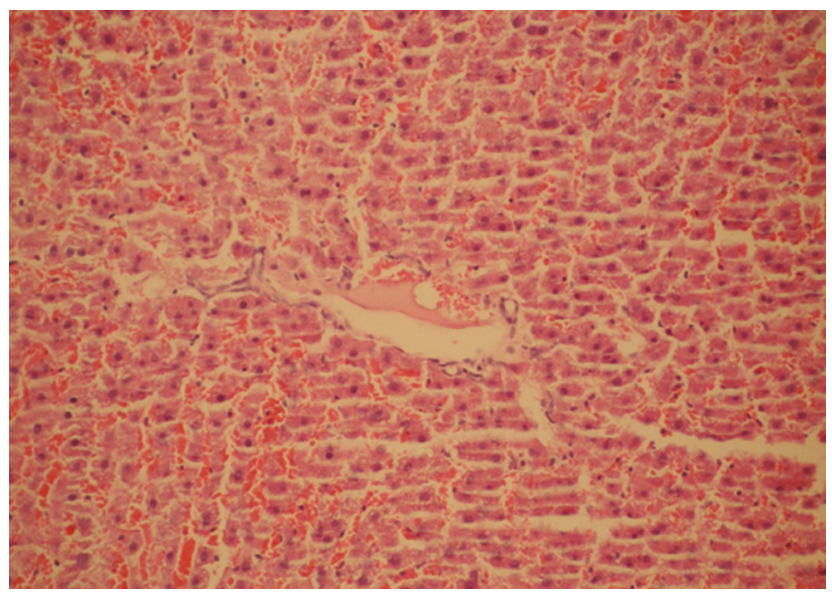

Fig. 3. Enlargement of portal veins and congestion of sinusoids (H\&E, X100).

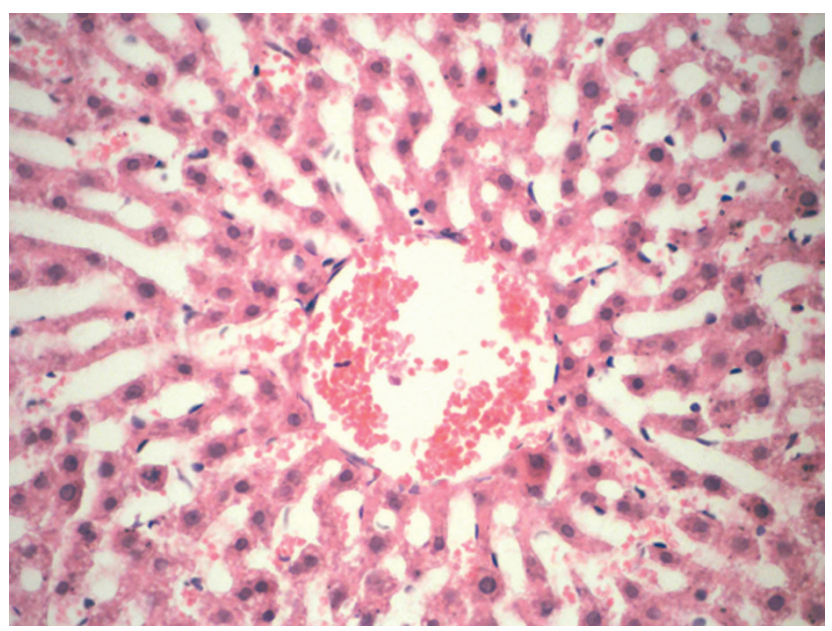

Fig. 4. Congestion in central vein and enlargement of sinusoids (H\&E, X200).

vera tablets containing $500 \mathrm{mg}$ of an extract of A. barbadensis for about 4 weeks in addition to zinc and vitamin $\mathrm{C}$ 


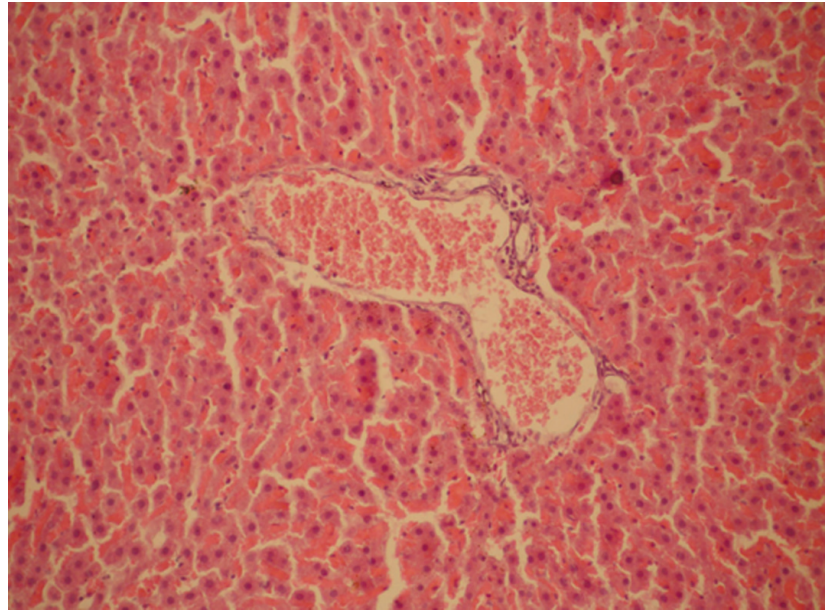

Fig. 5. Distinctive enlargement of portal vein and congestion (H\&E, X200).

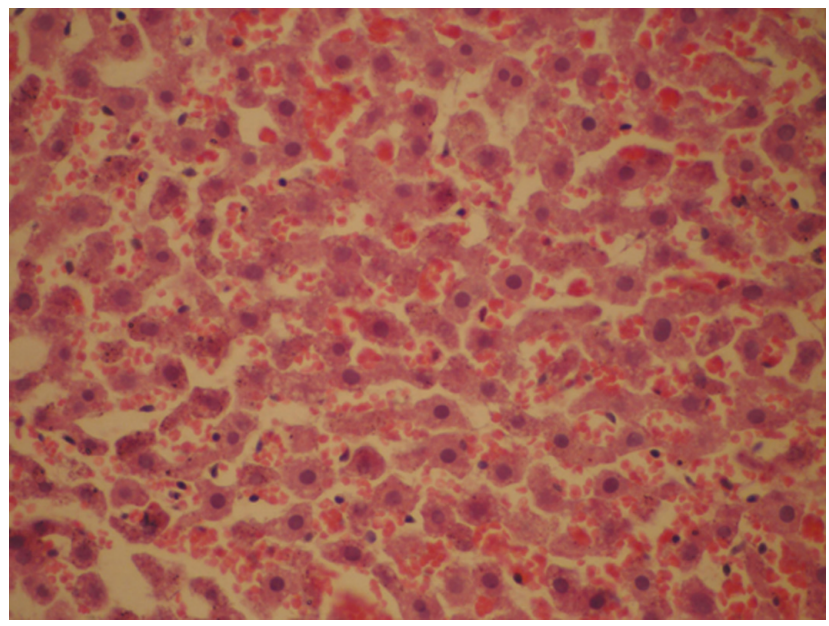

Fig. 7. Binucleation in hepatocytes and increase in chromatins (H\&E, X400).

supplements as directed by the manufacturer was also diagnosed with toxic hepatitis (Rabe et al.).

According to literature, A. vera extract reduced the cytotoxic effect of liver cell (Norikura et al., 2002). It was also reported that $A$. vera gel extract prevented the hepatotoxicity caused by glibenclamide (Can et al., 2004). In a study searching the effect of different aqueous extracts of $A$. vera on liver metabolism revealed that the activity of aminopyrene $\mathrm{N}$ demethylase was greatly reduced (Telefo et al., 2002).

Limited studies were conducted to search the effect of soybean oil on liver. It was proven with a study that soybean oil prevents liver damage related to parenteral nutrition (Nishimura et al.). In another study it was emphasized that consumption of soy provided benefits to control lipid levels (Lin et al., 2005). However, it was indicated that raw unprocessed soybean oil contains a toxic factor and it downgrades the growth of rats pups (Ikegami et al., 2006).

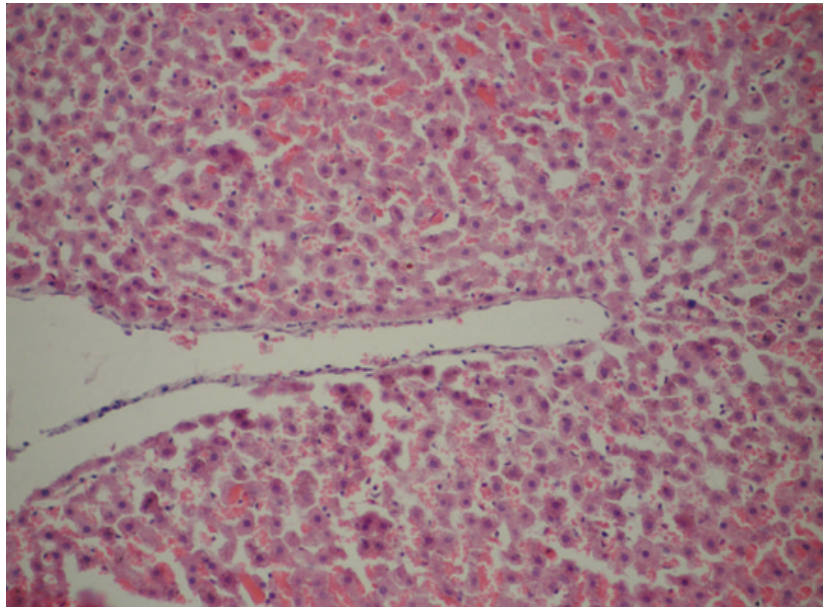

Fig. 6. Enlargement of central vein and congestion (H\&E, X200).

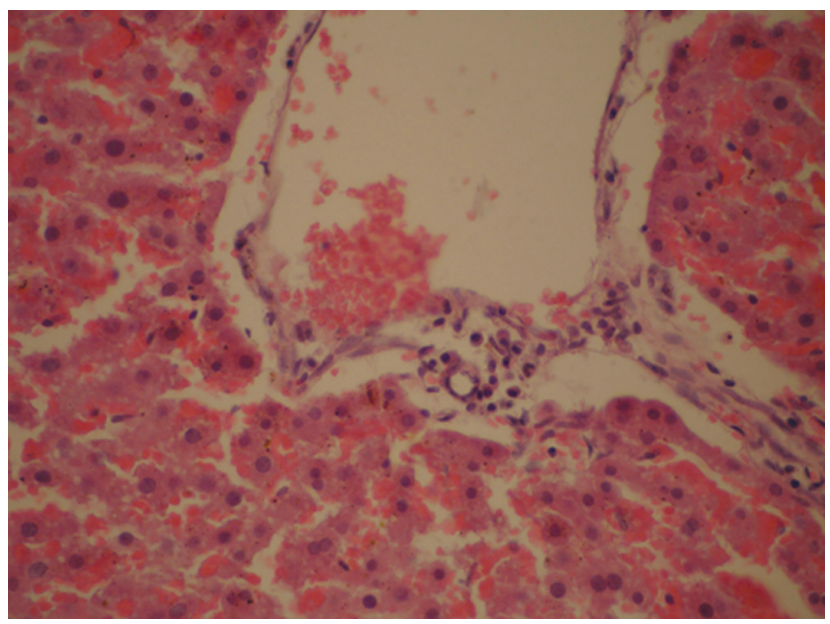

Fig. 8. Infiltration of plasmocytes in portal area (H\&E, X400).

Local use of soybean oil reveals the inflammatory reaction, and if present in the blood circulation system, provides antiinflammatory effect. (Benjamin et al., 1997).

In this study it was shown that the use of A. barbadensis in combination with soybean oil showed a synergistic effect on hepatocytes. For example the congestion observed in portal veins in group 2 was less severe than that of group 3. Plasmocyte infiltration observed in group 3 showed that inflammatory reaction was also revealed. In addition, it also should be considered that plasma cells play an important role in immunity, and especially, in inflammatory response mechanism by secreting immunoglobulins. Since no observed mononuclear inflammatory cell infiltration (plasmocyte) occurred in group 2 , it indicates $A$. barbadensis also have antiinflammatory effect. This conclusion was also supported by previous studies reported in the literature (Syed et al., 1996; Prabjone et al., 2006). It could be thought that degenerative changes such as nuclear enlargement in hepatocytes, 
binucleation and slight chromatin increase in liver can happen as an response to degeneration which may occur depending on a high dose is because the dose used in this study was equivalent to the dose suggested for humans. According to this information, it could be said that if they are used in appropriate dose both $A$. barbadensis and soybean oil cannot have toxic effect on hepatocytes.
This study showed that $A$. barbandesis and soybean oil can have degenerative effect on liver cell if they are used in high doses and they may increase harmful effect on the other. This study was conducted on light microscopic level and it is believed that further studies conducted with electron microscopic level along with the mechanism of action of $A$. barbendensis will give more detailed information.

KOSIF, R.; YıLMAZ, F.; EVRENDILEK, G.A. \& DıRAMALı, M. Efectos histopatológicos de Aloe Barbadensis y aceite de soya en hígado de rata. Int. J. Morphol., 28(4):1101-1106, 2010.

RESUMEN: Aloe Barbadensis, una especie de Aloe vera, es una planta popular usada por el común de las personas y también en la medicina alternativa. El estudio tuvo como objetivo analizar los efectos del Aloe Barbadensis y aceite de soya en el hígado. Para el estudio se emplearon ratas Wistar hembras Albino y se dividieron en 3 grupos: grupo control I sin tratamiento; grupo II A. barbadensis disuelta en aceite de soja (25 mg / día), y grupo III tratado sólo con aceite de soja (500 mg / día). Fueron extraídas biopsias del lóbulo derecho del hígado de las ratas y luego se analizaron con microscopio de luz. En el grupo I el hígado de las ratas era normal. En los grupos II y III, se observó aumento del tamaño nuclear, leve aumento de la cromatina y degeneración hidrópica y binucleación en algunos hepatocitos. La histología hepática mostró la congestión en las venas porta, sinusoides y las centrales. En el grupo III, la congestión venosa portal y en el Grupo II la congestión sinusoidal fue evidente. Además, el Grupo III reveló infiltración de plasmocitos en áreas portales. El uso de soja con Aloe Barbadensis es sinergista y aumenta cada uno de otros efectos. Infiltraciones mononucleares en el grupo III determinan la reacción inflamatoria. Sin embargo, no observamos infiltración mononuclear en el Grupo II, éste mostró efectos antiinflamatorios de la Aloe Barbadensis. Esto determina que, dependiendo de la dosis usada de Aloe Barbadensis, los efectos tóxicos pueden cambiar. Si es usado en altas dosis Aloe Barbadensis puede producir efectos tóxicos en los hepatocitos.

PALABRAS CLAVE: Aloe barbadensis; Poroto de soya; Rata; Hígado; Efecto.

\section{REFERENCES}

Avila, H.; Rivero, J., Herrera, F., Fraile, G. Cytotoxicity of a low molecular weight fraction from Aloe vera (Aloe barbadensis Miller) gel. Toxicon, 35:1423-30, 1997.

Azfal, M.; Ali, R.; Hassan, H.; Sweedan, N. \& Dhami, M. S. Identification of some prostanoids in Aloe vera extracts. Planta Med., 57:38-40, 1991.

Benjamin, C. F.; Figueiredo, R. C.; Henriques, M. G. \& BarjaFidalgo, C. Inflammatory and anti-inflammatory effects of soybean agglutinin. Braz. J. Med. Biol. Res., 30:873-81, 1997.

Can, A.; Akev, N.; Ozsoy, N.; Bolkent, S.; Arda, B. P.; Yanardag, R. \& Okyar, A. Effect of Aloe vera leaf gel and pulp extracts on the liver in type-II diabetic rat models. Biol. Pharm. Bull., 27:694-8, 2004.

Danhof, I. E. \& McAnally, B. H. Stabilised Aloe vera effect on human skin cells. Drug Cosmet Ind., 52:105-6. 1983.

Egger, S.; Brown, G. S.; Kelsey, L. S.; Yates, K. M.; Rosenberg, L. J. \& Talmadge, J. E. Studies on optimal dose and administration schedule of a hematopoietic stimulatory beta-(1,4)-linked mannan. Int. J. Immunopharmacol., 18:113-26, 1996.
El Gendy, S.; Hessien, M.; Abdel Salam, I. M.; Morad, M.; ELMagraby, K.; Ibrahim, H. A.; Kalifa, M. H. \& El-Aaser, A. A. Evaluation of the possible antioxidant effects of soybean and nigella sativa during experimental hepatocarcinogenesis by nitrosamine precursors. Turk. J. Biochem., 32:5-11, 2007.

Gali-Muhtasib, H.; Diab-Assaf, M.; Boltze, C.; Al-Hmaira, J.; Hartig, R.; Roessner, A. \& Schneider-Stock, R. Thymoquinone extracted from black seed triggers apoptotic cell death in human colorectal cancer cells via a p53dependent mechanism. Int. J. Oncol., 4:857-866, 2004.

Grindlay, D. \& Reynolds T. The Aloe vera phenomenon: a review of the properties and modern uses of the leaf parenchyma gel. J. Ethnopharmacol., 16:117-51, 1986.

Hu, Y.; Xu, J. \& Hu, Q. Evaluation of antioxidant potential of Aloe vera (Aloe barbadensis Miller) extracts. J. Agric. Food Chem., 51:7788-91, 2003.

Ikegami, S.; Tousen, Y.; Ishimi, Y.; Umegaki, K. \& Nakashima, Y. Possible adverse effects of soy isoflavone mixture of pregnant and lactating rats and their suckling pubs. $J$. of Health Science, 52:558-67, 2006.

Kamei, M.; Ohgaki, S.; Kanbe, T.; Niiya, I.; Mizutani, H.; MatsuiYuasa, I.; Otani, S. \& Morita, S. Effects of highly hydrogenated soybean oil and cholesterol on plasma, liver cholesterol, and fecal steroids in rats. Lipids, 30:533-9, 1995. 
Kanamoto, R.; Azuma, N.; Miyamoto, T.; Saeki, T.; Tsuchihashi, Y. \& Iwami, K. Soybean resistant proteins interrupt an enterohepatic circulation of bile acids and suppress liver tumorigenesisinduced by azoxymethane and dietary deoxycholate in rats. Biosci. Biotechnol. Biochem., 65:999$1002,2001$.

Kim, H. S.; Kacew, S. \& Lee, B. M. In vitro chemopreventive effects of plant polysaccharides (Aloe barbadensis Miller, Lentinus edodes, Ganoderma lucidum and Coriolus versicolor). Carcinogenesis, 20:1637-40, 1999.

Kim, H. S. \& Lee, B. M. Inhibition of benzo[a]pyrene-DNA adduct formation by Aloe barbadensis Miller. Carcinogenesis, 18:771-6, 1997.

Kuo, P. L.; Lin, T. C. \& Lin, C. C. The antiproliferative activity of aloe-emodin is through p53-dependent and p21-dependent apoptotic pathway in human hepatoma cell lines. Life. Sci., 71:1879-92, 2002.

Lee, K. Y.; Weintraub, S. T. \& Yu, B. P. Isolation and identification of a phenolic antioxidant from Aloe barbadensis. Free Radical Biol. Med., 28:261-5, 2000.

Lin, C. Y.; Tsai, C. Y. \& Lin, S. H. Effects of soy components on blood and liver lipids in rats fed high-cholesterol diets. World J. Gastroenterol., 11:5549-52, 2005.

Nishimura, M.; Yamaguchi, M.; Naito, S. \& Yamauchi, A. Soybean oil fat emulsion to prevent TPN-induced liver damage: possible molecular mechanisms and clinical implications. Biol. Pharm. Bull., 29:855-62, 2006.

Norikura, T.; Kennedy, D. O.; Nyarko, A. K.; Kojima, A. \& Matsui-Yuasa, I. Protective effect of aloe extract against the cytotoxicity of 1,4-naphthoquinone in isolated rat hepatocytes involves modulations in cellular thiol levels. Pharmacol. Toxicol., 90:278-84, 2002.

Paulsen, E.; Korsholm, L. \& Brandrup, F. A double-blind, placebo-controlled study of a commercial Aloe vera gel in the treatment of slight to moderate psoriasis vulgaris. JEADV, 19:326-31, 2005.

Prabjone, R.; Thong-Ngam, D., Wisedopas, N., Chatsuwan, T., Patumraj, S. Anti-inflammatory effects of Aloe vera on leukocyte-endothelium interaction in the gastric microcirculation of Helicobacter pylori-infected rats. Clin. Hemorheol. Microcirc., 35:359-66, 2006

Rabe, C.; Musch, A.; Schirmacher, P.; Kruis, W. \& Hoffmann, R. Acute hepatitis induced by an Aloe vera preparation: A case report. World J. Gastroenterol., 11:303-4, 2005.
Rodrigues, H. G.; Diniz, Y. S.; Faine, L. A.; Galhardi, C. M.; Burneiko, R. C.; Almeida, J. A.; Ribas, B. O. \& Novelli, E. L. Antioxidant effect of saponin: potential action of a soybean flavonoid on glucose tolerance and risk factors for atherosclerosis. Int. J. Food Sci. Nutr., 56:79-85, 2005.

Shida, T.; Yagi, A.; Nishimura, H. \& Nishioka, I. Effect of Aloe extract on peripheral phagocytosis in adult bronchial asthma. Planta Med., 51:273-5, 1985.

Syed, T. A.; Ahmad, S. A.; Holt, A. H.; Ahmad, S. A.; Ahmad, S. H. \& Afzal, M. Management of psoriasis with Aloe vera extract in a hydrophilic cream: a placebo-controlled, doubleblind study. Trop. Med. Int. Health, 1:505-9, 1996.

Tekin F.; S,ahin, O.; Karasu, Z.; Nart, D.; Özütemiz, O.; Ersöz, G.; Batur, Y. \& I'lter, T. Severe toxic hepatitis due to Aloe vera: Case report. Akademik Gastroenteroloji Dergisi, 5:134139, 2006.

Telefo, P. B.; Moundipa, P. F. \& Tchouanguep, F. M. Oestrogenicity and effect on hepatic metabolism of the aqueous extract of the leaf mixture of Aloe buettneri, Dicliptera verticillata, Hibiscus macranthus and Justicia insularis. Fitoterapia, 73:472-8, 2002.

Wei, H.; Bowen, R.; Cai, Q.; Barnes, S. \& Wang, Y. Antioxidant and antipromotional effects of the soybean isoflavone genistein. Proc. Soc. Exp. Bio. Med., 208:124-30, 1995.

Winters, W.; Benavides, R. \& Clouse, W. J. Effects of aloe extracts on human normal and tumor cells in vitro. Econ. Bot., 35:8995,1981 .

Yagi, A.; Harada, N., Schimomura, K., Nishioke, I. Bradykinindegrading glycoprotein in Aloe arborescems var. natalensis. Planta Med., 53:19-21, 1987.

Zhang, L. \& Tizard, I. R. Activation of a mouse macrophage cell line by acemannan: the major carbohydrate fraction from Aloe vera gel. Immunopharmacology, 35:119-28, 1996.

Correspondence to:
Dr. Rengin Kosif
University Faculty of Medicine
Department of Anatomy Golkoy Campus 14280
Bolu,
TURKEY

E-mail: rengink@yahoo.com
Received: 06-05-2010

Accepted: 19-08-2010 